\title{
CALL FOR PAPERS AND PANELS: SSHA 1982 MEETING
}

The Seventh Annual Meeting of the Social Science History Association will be held November 4-6 at Indiana University in Bloomington, Indiana. Those wishing to organize a panel, present a paper, chair a session, serve as a discussant, or offer suggestions for the program are invited to contact:

\section{Program Committee Chair:}

Elyce J. Rotella

Economics Department

Ballentine Hall

Indiana University

Bloomington, IN 47405

(812) $337-7858$

(812) 337-1021 (messages)
Co-Chair

Ray Shortridge

Political Science Department

University of Louisville

Louisville, KY 40292

(502) $966-2913$

The full membership of the Program Committee will be announced at the 1981 meeting in Nashville. Suggestions for papers, panels, or other aspects of the program should be made to either of the chairs or to the member of the committee responsible for the appropriate substantive area.

Proposals for entire panels (usually 2-3 papers and 2 discussants) and proposals for individual papers will be accepted.

Proposals for panels should include a title; a one-page description of the panel which discusses the rationale for the panel as constituted and the importance of the topic; a one-page précis for each paper to be included on the panel; a short vitae (including addresses and phone numbers) for each person involved in the panel (chair; organizer, if different from the chair; paper presenters; and discussants). Panels may be in the form of round-table discussions. Proposals for round tables should include a discussion of the topic and a description of the expected contribution from each member of the round table. Submit a brief vitae for each member.

Organizers of panels and round tables should keep in mind the commitment of the Social Science History Association to interdisciplinary and multidisciplinary interchange. Panels which include members from various disciplines will be viewed most favorably by the Committee. 
Proposals for individual papers should include a one-page précis and a brief vitae. Program Committee members will organize individual papers into panels.

All proposals must be received no later than February 22, 1982. Notifications of the final composition of the program will be sent by May 15 . Deadline for submission of completed papers is October 1, 1982.

\section{ROCKEFELLER UNIVERSITY GRANTS-IN-AID}

The Rockefeller University has made 22 grants-in-aid to support projects requiring substantial research in the holdings of the Rockefeller Archive Center during 1981. The grant recipients were Edward Nelson Akin, Ellen Corwin Cangi, David T. Courtwright, Hamilton Cravens, Elizabeth Fee, Jacqueline Goggin, Karen J. Greenberg, Rogers Hollingsworth, Kenneth M. Ludmerer, James H. Madison, Harvey G. Neufeldt, Penelope Peterson, Stephen G. Rabe, Priscilla Mary Roberts, William Schneider, William B. Scott, Michael W. Sedlak, Laurence D. Smith, Bernard J. Ulozas, Jr., Mark H. Van Pelt, Robert R. Weyeneth, and Elin L. Wolfe.

Grants of not more than $\$ 1000$ will be made to graduate students or advanced scholars engaged in similar projects during the year 1982. Applications for grant year 1982 should be made before December 31,1981 . The names of recipients will be announced on or before March 31, 1982.

Inquiries about the program and the open collections at the Center should be addressed to: Director, Rockefeller Archive Center, Pocantico Hills, North Tarrytown, New York 10591.

\section{THIRD INTERNATIONAL CES CONFERENCE OF EUROPEANISTS: "PERIODS AND CYCLES IN EUROPE-PAST AND PRESENT"}

The Council for European Studies announces the convening of the Third International CES Conference of Europeanists, to be held in Washington, D.C., April 21 to May 1, 1982. The conference will consist of a series of panels closely related to a central theme-"Periods and Cycles in Europe-Past and Present"-as elaborated in the statement of theme below. There will also be a limited number of other panels on topics of 
general interest. American, European, and other scholars of Europe are invited to submit their suggestions for participants, panels, and specific papers to the Program Committee by November 1, 1981. Panel and paper proposals should be accompanied by a short précis of proposed content and an abbreviated vitae. Conference groups and other cooperating associations are invited to propose additional panels related to the central theme.

\section{STATEMENT OF THEME}

The possibility of regular cycles and of distinct periods in the history of societies has long intrigued social observers and analysts. Conceiving of cycles and periods has two advantages. The concepts can help to organize the seeming flux of economic, social, and political life and point to continuities where only change seemed present. They might also offer integrative frameworks for a wide range of seemingly disparate phenomena.

In none of the social science disciplines nor in the humanities, however, are either cycles or periods the predominant organizing metaphor. Even less is there agreement among even those who use the concepts about the existence of specific cycles or periods. Nonetheless, there is widespread usage of this terminology. In economics, where they have been extensively studied for some time, a number of specific cycles have been distinguished. In history, political science, sociology, and some of the humanities, they also have received increased attention in recent years. This expanded use of the concepts, and the challenges they pose, invite our attention, especially as much of the work has utilized data drawn from the European context.

The Program Committee has conceived of the central theme not as an assertation of conviction, but rather as a response to these challenges and a stimulus to creative thought. There is no assumption that cycles and periods are necessarily the appropriate way of thinking of social life. Instead we propose that the Conference focus its attention on whether cycles and periods exist and are useful organizing concepts, what might be their causes and effects, and how they might relate to one another and to other aspects of European social, economic, and political life. Some possible themes for specific panels are suggested below; submission of others is encouraged.

The general theme is intended to invite contributions from scholars in any of the disciplines of the social sciences and humanities. Interdisciplinary papers and panels are encouraged, as are those that span a range of European countries and historical periods. Papers and panels that include 
primarily European cases, but non-European ones as well, will also be accepted.

\section{POSSIBLE THEMES FOR PANELS}

\begin{tabular}{|c|c|}
\hline $\begin{array}{l}\text { Social Mobilization, Reform, } \\
\text { and Repression }\end{array}$ & $\begin{array}{l}\text { Centralization/Decentralization } \\
\text { Demographic }\end{array}$ \\
\hline $\begin{array}{l}\text { The "Life Cycle" of Social } \\
\text { Movements }\end{array}$ & $\begin{array}{l}\text { International Hegemonic Cycles } \\
\text { and Periods }\end{array}$ \\
\hline Innovation & Women's Position: Cyclical \\
\hline "Great Awakenings" & Change or Evolution \\
\hline Generations & Family: Structure and Feeling \\
\hline Business Cycles-Kitchin, Juglar, & Natural Resources \\
\hline $\begin{array}{l}\text { Kondratieff-and Their Political } \\
\text { and Other Correlates }\end{array}$ & Disease \\
\hline Artistic Creativity & Decolonization \\
\hline Product Cycles and Their Political & $\begin{array}{l}\text { Electoral and Political Business } \\
\text { Cycles }\end{array}$ \\
\hline Fashion & Depression \\
\hline Labor Unrest & \\
\hline
\end{tabular}

For any of these, and others which might be proposed, panels and papers may want to address conceptual or substantive issues, or both. It is also expected that the specific subject matter of any panel would focus on a narrower topic within these general themes.

The conference program committee is composed of the following:

Peter Lange (Chair), Center for European Studies, Harvard University

Peter Katzenstein, Cornell University

Michael Piore, M.I.T.

Louise Tilly, University of Michigan

Proposals for panels and paper précis should be addressed to: Conference 1982, Council for European Studies, 1404 International Affairs Building, Columbia University, New York, N.Y. 10027. 


\section{COMPARATIVE RESEARCH:}

\section{A NEWS MAGAZINE}

Comparative Research is a quarterly news magazine that reports all new developments in cross-national, cross-cultural, and comparative research throughout the world-as we learn about them. Regular features include:

- summaries of major research projects and major research programs that have recently been completed

- programs of institutes that are particularly active in comparative research

- abstracts and listings of new books, articles, and papers

- recent and forthcoming conferences

- fellowship and grant programs

- research resources useful to comparativists

- educational resources for the training of comparativists

- special reports, such as recommendations for conferences

- letters from readers expressing opinions on methods and research results, suggestions for new approaches, and so forth

There are two ways to subscribe to Comparative Research:

(1) An individual may join the Comparative Interdisciplinary Studies Section (CISS) of the Interactional Studies Association, which sponsors the magazine. The membership fee is $\$ 5$ per year for CISS membership plus ISA dues. Write to: Judith Cain, International Studies Association, James F. Byrnes International Center, University of South Carolina, Columbia, SC 29208.

(2) Individuals and libraries may subscribe to Comparative Research without joining ISA. A year's subscription is $\$ 20$. Make check out to International Studies Association, and send it to: Judith Cain, International Studies Association, James F. Byrnes International Center, University of South Carolina, Columbia, SC 29208.

For a free sample copy write to the above address. 


\section{THE UNIVERSITY OF TEXAS AT ARLINGTON}

\section{Announces}

\section{THE WEBB-SMITH ESSAY COMPETITION \$500 AWARD}

For the best essay of 10,000 words or less on the topic:

\section{The Family and Historical Change}

Manuscripts for 1982 judging must be submitted by

\section{February 1, 1982}

Submittal forms and additional information should be obtained from the Walter Prescott Webb Memorial Lectures Committee, Department of History, Box 19529. The University of Texas at Arlington. Arlington. Texas 76019

The winning essay will be submitted for publication as part of The Walter Prescott Webb Memorial Lectures Series 